\title{
ANALIZY PRZESTRZENNE W BADANIACH NAD JAKOŚCIĄ ŻYCIA W MIASTACH*
}

\section{JAKOŚĆ ŻYCIA}

Jakość życia jest szeroko akceptowanym celem rozwoju społeczeństw umieszczanym $\mathrm{w}$ wielu dokumentach strategicznych. Jednocześnie bardzo często pojęcie to pozbawione jest jednoznacznej definicji i metod pomiaru. Bardzo często jakość życia jest rozumiana jako zestaw ilościowych wskaźników społecznych i ekonomicznych. Przekonanie o bezpośredniej zależności jakości życia od warunków ekonomicznych doprowadziło do uznania produktu krajowego brutto (PKB) i innych wskaźników ekonomicznych za główne i wystarczające wskaźniki rozwoju społeczeństw. Warunki ekonomiczne i kondycja gospodarki sa niewątpliwie istotnymi czynnikami jakości życia, jednak do oceny warunków życia ludności niezbędne jest także uwzględnienie innych aspektów ${ }^{1}$. Przyjęty przez ONZ wskaźnik rozwoju społecznego (ang. Human Development Index), spełnia ten cel poprzez uwzględnienie oczekiwanej długości życia, poziomu edukacji oraz dochodu narodowego według parytetu siły nabywczej pieniądza². Wskaźnik lepszego życia (ang. Better Life Index) wprowadzony przez Organizację Współpracy Gospodarczej i Rozwoju (Organization for Economic Co-operation and Development, OECD) uwzględnia 11 ekonomicznych, społecznych i środowiskowych wymiarów dobrostanu³. Zestaw miar

\footnotetext{
* W artykule wykorzystano dane pochodzące z projektów sfinansowanych ze środków Narodowego Centrum Nauki przyznanych na podstawie decyzji numer DEC-2011/03/N/HS4/00368 i DEC-2012/05/B/HS4/03850. W artykule wykorzystano dane pochodzące z projektu „Licz na zieleń” prowadzonego przez Fundację Sendzimira i współfinansowanego przez Szwajcarię w ramach szwajcarskiego programu współpracy z nowymi krajami członkowskimi Unii Europejskiej. Podczas pracy nad artykułem Michał Czepkiewicz był uczestnikiem Środowiskowych studiów doktoranckich $\mathrm{w}$ zakresie nauk o środowisku przyrodniczym w ramach programu Unikatowy Absolwent $=$ Możliwości. Współpraca autorów nad artykułem była możliwa dzięki wizycie Michała Czepkiewicza w Department of Geography w San Diego State University, sfinansowanej w ramach Fulbright Junior Advanced Research Award.

${ }^{1}$ E. Diener, M. E. P. Seligman, Beyond Money: Toward an Economy of Well-being, „Psychological Science in the Public Interest” 5, 2004, nr 1, s. 1-31.

${ }^{2}$ United Nations Development Programme, Human Development Reports, http://hdr.undp. org/en/statistics/hdi.

${ }^{3}$ OECD, OECD Better Life Index, http://www.oecdbetterlifeindex.org/, wskaźnik zawiera także wymiar subiektywnego dobrostanu.
} 
wykorzystywanych do pomiaru jakości życia w takim ujęciu odzwierciedla wyznawane w społeczeństwie wartości i przyjmowane cele rozwojowe.

Zaletą wykorzystania ilościowych wskaźników ekonomicznych i społecznych do badania jakości życia jest możliwość ich porównywania i obiektywność rozumiana jako niezależność od indywidualnych cech osób, których dotyczy pomiar. Jednocześnie wskaźniki takie dają głównie obraz możliwości, jakie stwarza ludziom otoczenie, bez uwzględniania innych istotnych czynników składających się na dobre życie, takich jak dobre samopoczucie lub zadowolenie z życia i jego aspektów. Wskaźniki ekonomiczne i społeczne odzwierciedlają też głównie punkt widzenia decydentów i pewien uznany społecznie zestaw wartości, pomijając różnice indywidualne w ocenie tego, co jest w życiu ważne. Z tych i innych powodów uważa się wskaźniki obiektywne za element konieczny, ale nie wystarczający do badania jakości życia ${ }^{4}$. Proponowanym uzupełnieniem jest badanie subiektywnej jakości życia określanej także mianem subiektywnego dobrostanu (ang. subjective well-being) ${ }^{5}$.

W badaniach subiektywnego dobrostanu podstawą do wyliczenia wskaźników sa odpowiedzi respondentów na popularne w socjologii i psychologii pytania psychometryczne. W ten sposób ocena jakości życia dokonywana jest przez jednostki i dopiero później agregowana do wyższych poziomów. Pomiarów subiektywnego dobrostanu dokonuje się w podziale na wymiar poznawczy, afektywny i psychologiczny:

- dobrostan afektywny dotyczy doświadczania pozytywnych i niedoświadczania negatywnych emocji i uczuć;

- dobrostan poznawczy związany jest z ocena życia jako całości lub określonych jego aspektów, określany także stopniem zadowolenia lub satysfakcji;

- dobrostan psychologiczny dotyczy takich aspektów funkcjonowania człowieka, jak zgodność z wyznawanymi zasadami, samorozwój czy posiadanie sensu i celu w życiu ${ }^{6}$.

Do subiektywego dobrostanu włącza się także miary szczęścia i zdrowia. Szczęście jest pojęciem złożonym i nieuchwytnym ${ }^{7}$, jednak bywa wykorzystywane w badaniach jakości życia ze względu na jego powszechność w języku i kulturze. Samoocena stanu zdrowia wywodzi się z definicji zdrowia przyjętej przez Światową Organizację Zdrowia - jest to „stan pełnego fizycznego, umysłowego i społecznego dobrostanu, a nie tylko całkowity brak choroby czy kalectwa"8. Samoocena stanu zdrowia jest szeroko stosowana jako łatwo dostępna miara całościowej oceny kondycji psychofizycznej.

Psychometryczne miary subiektywnego dobrostanu nie sa pozbawione wad, a ich pozyskanie jest wymagajace. Odpowiedzi mogą być zależne m.in. od cech osobowości, wyznawanych wartości czy aktualnego samopoczucia w mo-

${ }^{4}$ R. Costanza et al., Quality of Life: An Approach Integrating Opportunities, Human Needs, and Subjective Well-being, „Ecological Economics” 61, 2007, nr 2-3, s. 267-276; E. Diener, M. E. P. Seligman, op. cit., s. 1-31.

${ }_{5}^{5}$ E. Diener, Subjective Well-being, „Psychological Bulletin” 95, 1984, nr 3, s. 542-575.

${ }^{6}$ OECD, OECD Guidelines on Measuring Subjective Well-being, OECD Publishing 2013.

${ }^{7} \mathrm{~W}$. Tatarkiewicz, O szczęściu, Warszawa 1962.

${ }^{8}$ World Health Organization, WHO definition of Health, http://www.who.int/about/definition/ en/print.html. 
mencie badania ${ }^{9}$. Jednocześnie miary takie są jedynym obecnie dostępnym źródłem indywidualnych ocen jakości życia i nie moga być wprost zastapione przez zewnętrzne oceny. W ostatnich latach, dzięki wzrostowi zainteresowaniu tematyką wśród naukowców i decydentów, nastapił dynamiczny postęp skutkujący powszechniejszym wykorzystaniem miar w praktyce. Obecnie istnieja już liczne wiarygodne narzędzia pomiarowe i praktyczne wskazówki na temat całego procesu prowadzenia badań ${ }^{10}$. Instytucje, takie jak $\mathrm{OECD}^{11} \mathrm{i}$ brytyjskie Office for National Statistics $(\mathrm{ONS})^{12}$, nie tylko stosują miary subiektywnego dobrostanu w połączeniu ze wskaźnikami obiektywnymi, lecz także aktywnie uczestnicza w ich rozwoju i upowszechnianiu. W Polsce od kilkunastu lat prowadzi się badania subiektywnej jakości życia w ramach Diagnozy Społecznej ${ }^{13}$. Pewne elementy subiektywnego dobrostanu uwzględniane sa także $\mathrm{w}$ badaniach jakości życia w skali miejskiej, takich jak Badanie jakości życia w Poznaniu ${ }^{14}$.

Zarówno obiektywne wskaźniki jakości życia, jak i miary subiektywnego dobrostanu tworzone sa zwykle na poziomie państw, regionów lub miast. W ten sposób pozwalaja na porównania międzynarodowe, międzyregionalne i międzymiejskie. Takie ujęcie, choć użyteczne, nie pozwala jednak na wykrycie zróżnicowania w poziomie jakości życia wewnątrz miast. Jest to szczególnie ważne w sytuacji, gdy miasta są bardzo niejednorodne wewnętrznie pod względem struktury urbanistycznej, społecznej i ekonomicznej, a co za tym idzie - także pod względem jakości życia. Istnieje szereg aspektów i czynników jakości życia, które mogą się różnić pomiędzy częściami miast i powinny być badane w ujęciu przestrzennym. Kolejne części artykułu koncentrują się na czynnikach jakości życia w miastach, ich zróżnicowaniu przestrzennym, a także na zastosowaniu analiz przestrzennych w badaniu jakości życia za pomoca wskaźników obiektywnych i subiektywnych.

\section{CZYNNIKI JAKOŚCI ŻYCIA W MIASTACH}

Od czasu rewolucji przemysłowej miasta stają się w coraz większym stopniu podstawowym środowiskiem życia człowieka. Wiele regionów świata gwałtownie się urbanizuje, a udział ludzi mieszkających w miastach w ogóle ludności niedawno przekroczył połowę ${ }^{15}$. W Polsce wskaźnik ten wynosi po-

${ }^{9}$ W. Pavot, The Assessment of Subjective Well-being: Successes and Shortfalls, w: M. Reid, R. J. Larsen (red.), The Science of Subjective Well-Being, New York 2008.

${ }^{10}$ OECD, op. cit.,

${ }^{11}$ OECD, How's Life? Measuring Well-being, OECD Publishing 2013.

${ }^{12}$ Office for National Statistics, Measuring National Well-being, http://www.ons.gov.uk/ons/ guide-method/user-guidance/well-being/index.html.

${ }^{13}$ J. Czapiński, Diagnoza społeczna 2013: Warunki i jakość życia Polaków, Warszawa 2013.

${ }_{14}$ M. Cichocki, P. Jabkowski, A. Siatkowski, Wskaźniki jakości życia mieszkańców Poznania 2010: Raport z badań, Poznań 2010.

${ }^{15}$ UN DESA, World Urbanization Prospects, the 2011 Revision, http://esa.un.org/unup/, definicje obszarów według definicji krajowych urzędów statystycznych. 
nad $60 \%$, a w wielu krajach rozwiniętych ponad $80 \%{ }^{16}$. Kwestia jakości życia w miastach dotyczy więc dużej i wciąż rosnącej liczby osób. Zmienia sią także struktura przestrzenna miast. Ich rozlewanie się powoduje problemy infrastrukturalne, komunikacyjne, środowiskowe, zdrowotne i społeczne ${ }^{17}$. Jednocześnie wiele miast w Polsce podlega procesom wyludniania się. Odpływ mieszkańców do innych miast lub na przedmieścia położone poza granicami administracyjnymi miasta ma negatywne skutki dla budżetów miast. $\mathrm{Z}$ tego powodu polskie miasta coraz częściej wyrażają chęć utrzymania dotychczasowych mieszkańców w granicach miast i dzielnicach śródmiejskich i przyciagnięcia nowych, m.in. przez zapewnienie im dobrych warunków życia. W wielu miastach następują także dynamiczne zmiany w wewnętrznej strukturze społeczno-ekonomicznej ludności, mogące prowadzić to pogłębienia nierówności społecznych. Znaczenie tych procesów wskazuje na konieczność badania jakości życia w środowisku miejskim, a ich zrozumienie wymaga przestrzennego spojrzenia na miasto.

1. Środowisko miejskie bywa postrzegane jako negatywne i szkodliwe dla zdrowia. Wiąże się to m.in. z doświadczeniami miast przemysłowych XIX w. ${ }^{18}$ i współczesnymi problemami z zanieczyszczeniem powietrza i uciążliwościa transportu. Wiele cech środowiska miejskiego może rzeczywiście negatywnie wpływać na zdrowie i samopoczucie mieszkańców. Zanieczyszczenie powietrza wywołuje choroby układu oddechowego, a zatłoczenie i hałas prowadza do irytacji i problemów ze snem. Wiele negatywnych cech zostało zniwelowanych przez rozwój technologii i działania urbanistyczne, czynniki te wciąż jednak stanowią duże wyzwania dla współczesnych miast, czego przykładem moga być problemy Krakowa z zanieczyszczeniem powietrza. Mimo to w myśleniu o mieście następuje zwrot w kierunku pozytywnych aspektów środowiska miejskiego ${ }^{19}$. Miasto postrzegane jest jako dobre środowisko do życia, a dużo mówi się o jego cechach wspierających lub ograniczających aktywności związane z jakością życia. Do głównych aktywności tego rodzaju można zaliczyć życie społeczne, kontakt z przyrodą oraz aktywne i skuteczne przemieszczanie się.

2. Miasta od zawsze przyciagały mieszkańców nie tylko możliwością rozwoju ekonomicznego, lecz także możliwością nawiązania kontaktów społecznych i interesującym stylem życia. Relacje międzyludzkie są jednym z ważniejszych warunków dobrego samopoczucia, zdrowia i satysfakcji z życia. Choć ich jakość w dużej mierze zależy od cech indywidualnych, środowisko miejskie może je wspierać lub utrudniać. Dobrze zaprojektowana przestrzeń miejska skłania do przebywania na zewnątrz i brania udziału w życiu społecznym, poprawiając nie tylko kontakty międzyludzkie, ale także poczucie bezpieczeń-

16 Ibidem.

17 H. Frumkin, Urban Sprawl and Public Health, „Public Health Reports” 117, 2002, nr 3, s. 201-217.

18 P. Hall, Cities of Tomorrow: An Intellectual History of Urban Planning and Design in the Twentieth Century, New York 2002.

${ }^{19}$ H. Frumkin, Beyond Toxicity: Human health and the natural environment, „American Journal of Preventive Medicine” 20, 2001, nr 3, s. 234-240; M. Montgomery, Happy City: Transforming our Lives through Design, New York 2013. 
stwa ${ }^{20}$. Ulice, które sa przyjazne dla pieszych i wolne od uciążliwego ruchu samochodowego, pozwalają na rozwój relacji sąsiedzkich i budowanie kapitału społecznego ${ }^{21}$. Kawiarnie, restauracje i inne miejsca spotkań ułatwiają utrzymywanie istniejaccych znajomości i nawiązywanie nowych. Środowisko miejskie może także wspierać życie rodzinne, szczególnie możliwość spędzania czasu z dziećmi, m.in. przez dostępność placów zabaw. Za przyjazne mieszkańcom uznaje się więc części miast z dużą ilością miejsc spotkań, gdzie można się łatwo przemieszczać pieszo, a układ ulic i placów umożliwia spędzanie czasu wolne od zagrożeń i niedogodności związanych z ruchem samochodowym. Do utrzymania i poprawy warunków do wysokiej jakości życia społecznego potrzebne jest badanie dostępu do aktywności społecznych i kulturalnych, stopnia, w jakim cechy środowiska miejskiego wpierają życie społeczne, oraz oceny jakości życia społecznego w ujęciu przestrzennym.

Różnorodność życia społecznego związana z dzielnicami śródmiejskimi może być pożądana, ale może być też powodem ucieczki niektórych osób na przedmieścia. Niskie poczucie bezpieczeństwa, uciążliwość życia nocnego, zaniedbane budynki czy niechęć dzielenia przestrzeni z osobami o odmiennym statusie moga być kolejnym powodem do przenosin. Wiele osób wybiera przedmieścia dla ciszy, spokoju i dostępności zieleni w postaci własnego ogródka lub otwartych przestrzeni i lasów ${ }^{22}$. Chęć utrzymania dostępu do przyrody jest uzasadniona korzyściami potwierdzonymi przez liczne badania ${ }^{23}$ : przebywanie wśród zieleni pozwala zredukować stres, zrelaksować się i przywrócić zdolność do koncentracji, parki, skwery i inne elementy zieleni mogą stanowić także miejsca kultywowania relacji społecznych, a drzewa przyuliczne pozwalają m.in. redukować uciążliwość hałasu i dają schronienie przed słońcem. Rozległe tereny zieleni z odpowiednią infrastruktura stanowią także miejsca uprawniania sportu i aktywnego wypoczynku, co jest szczególnie ważne dla zdrowia i samopoczucia. Dostępność dużych parków o odpowiedniej jakości w pobliżu miejsca zamieszkania jest uważana za jeden $\mathrm{z}$ istotniejszych czynników miejskiej jakości życia. Tereny zieleni są zwykle nierównomiernie rozmieszczone w przestrzeni, mają też różne cechy i stwarzają warunki do różnych aktywności. Z tego powodu ważne jest nie tylko badanie ich dostępności i jakości, lecz także dostosowania do potrzeb i oczekiwań mieszkańców mieszkajacych w pobliżu ${ }^{24}$.

Ważnym aspektem życia w mieście jest możliwość przemieszczania się z miejsca na miejsce. Skuteczny transport pozwala zaoszczędzić czas i wpływa pozytywnie na zadowolenie mieszkańców, nieskuteczny może być źródłem frustracji i stresu ${ }^{25}$. Uzależnienie od komunikacji samochodowej może też mieć

${ }^{20}$ J. Gehl, Życie między budynkami, Kraków 2013; J. Jacobs, Śmierć i życie wielkich miast Ameryki, Warszawa 2014.

${ }_{21}$ D. Appleyard, Livable streets, Berkeley 1981.

22 K. Kajdanek, Suburbanizacja po polsku, Kraków 2012

${ }^{23}$ W. Sullivan, Wellbeing and Green Spaces in Cities, w: L. Bruton, R. Cooper (red.) Wellbeing and the Environment: A Comprehensive Guide, Oxford 2014; T. Hartig et al., Nature and Health, „Annual Review of Public Health” 35, 2014, s. 207-228.

24 E. Talen, The Spatial Logic of Parks, „Journal of Urban Design” 15, 2010, nr 4, s. 473-491.

25 A. Stutzer, B. S. Frey, Stress that Doesn't Pay: The Commuting Paradox, „Scandinavian Journal of Economics" 110, 2008, nr 2, s. 339-366. 
negatywny wpływ na zdrowie. Z kolei aktywne poruszanie się po mieście, pieszo lub rowerem, a nawet jako dojście do przystanków komunikacji miejskiej może być ważnym źródłem aktywności fizycznej korzystnej dla zdrowia i samopoczucia. Aktywny transport jest także mniej uciążliwy dla środowiska i innych mieszkańców, dlatego też wiele miast stara się propagować go poprzez tworzenie infrastruktury i różne działania promocyjne. Dlatego też zróżnicowanie przestrzenne jakości i dostępności komunikacji miejskiej oraz warunków aktywnego przemieszczania się jest ważnym aspektem badania jakości życia w miastach.

Wymienione aspekty środowiska miejskiego i różne formy aktywności związane z jakością życia mogą być w różny sposób odbierane i oceniane przez różne grupy mieszkańców miast. Przyzwyczajenia i indywidualne preferencje mają szczególnie duże znaczenie przy wyborze środków transportu. Mieszkańcy miast mają także różne potrzeby dotyczące życia społecznego, kontaktu z przyrodą i innych form aktywności. Priorytety życiowe i styl życia zmieniaja się z wiekiem i sytuacją rodzinna, są też kwestią osobistego wyboru i cech osobowości. Miasta powinny dawać każdemu możliwość realizacji preferowanego stylu życia, starając się jednocześnie ograniczać rodzaje aktywności, które sa uciążliwe dla innych, i promować te, które są korzystne ze względów społecznych, ekonomicznych i środowiskowych. Aby utrzymać i przyciagnąć mieszkańców, ważne jest rozumienie ich zmieniających się oczekiwań. Badania jakości życia powinny być więc uzupełniane o badania, jaki styl życia preferuja obecni mieszkańcy i osoby potencjalnie chętne do zamieszkania w mieście.

Chęć utrzymania i przyciagania mieszkańców nie jest jedynym powodem wzrostu znaczenia badań jakości życia w miastach. W niektórych miastach obserwuje się także odejście od skupienia wyłącznie na tworzeniu dobrych warunków ekonomicznych i stawiania wzrostu PKB jako głównego wskaźnika sukcesu. Sytuacja gospodarcza zachowuje znaczenie jako podstawa jakości życia, jednakże w wielu miastach znaczenie zyskuje zrównoważony rozwój. Rozwój taki w założeniu łączy wysoką jakość życia mieszkańców z rozwojem ekonomicznym i przyjaznością dla środowiska przyrodniczego. I chociaż takie hasła były umieszczane w miejskich strategiach już od dawna, dopiero w ostatnich latach obserwuje się więcej działań w kierunku ich realizacji. Jednym z czynników takiego zwrotu jest aktywność lokalnych społeczności i ruchów miejskich ${ }^{26}$ zbiegajacca się z rosnąca otwartością samorządów na partycypację społeczna. Zwiększenie udziału społecznego w planowaniu przestrzennym i tworzeniu budżetów miast pokazały, że priorytety mieszkańców są związane z jakością życia, a wiele postulatów dotyczy aktywnego transportu, jakości przestrzeni publicznej i terenów zieleni.

Tendencje te pozwalają wierzyć, że polskie miasta zmierzają w kierunku prawdziwie zrównoważonego rozwoju, którego wszystkie aspekty wzajemnie się wspieraja. Cechy środowiska miejskiego wspierające jakość życia sa

${ }^{26}$ L. Mergler, K. Pobłocki, M. Wudarski, Anty-bezradnik przestrzenny: prawo do miasta w działaniu, Warszawa 2013. 
często korzystne dla środowiska przyrodniczego. Mogą być też korzystne dla gospodarki: osoby szczęśliwe odnoszą większe sukcesy w życiu zawodowym, lepiej radza sobie z problemami oraz sa bardziej produktywne ${ }^{27}$. Wspieranie jakości życia można zatem traktować jako długoterminową inwestycję nie tylko w samopoczucie i zdrowie mieszkańców, lecz także w szerzej rozumiany stan dobrobytu, także ekonomicznego. Do realizacji tej wizji niezbędne są kompleksowe i wrażliwe na zróżnicowanie przestrzenne badania jakości życia w miastach. Kolejne części artykułu prezentują metody przestrzennego badania jakości życia w podziale na obiektywne wskaźniki społeczne, ekonomiczne i przestrzenne oraz subiektywne wskaźniki oparte na doświadczeniu i percepcji mieszkańców.

\section{WSKAŹNIKI EKONOMICZNE I SPOŁECZNE}

Wiele spośród ekonomicznych i społecznych wskaźników jakości życia może być przydatnych w planowaniu i zarządzaniu miejskim. Stan i charakterystyka demograficzna ludności, stopa bezrobocia, aktywność ekonomiczna ludności, wysokość dochodów czy ceny mieszkań to podstawowe miary pozwalające na identyfikację obszarów zamieszkiwanych przez różnorodne grupy demograficzne i społeczno-ekonomiczne i w związku z tym mające inne potrzeby i problemy. Śledzenie zmian w czasie pozwala wychwycić migracje i zmiany liczby ludności, pojawianie się i zanikanie enklaw biedy i bezrobocia czy procesy gentryfikacyjne objawiające się m.in. zmianami cen mieszkań. Wskaźniki takie dostarczaja podstawowej wiedzy koniecznej w zarządzaniu miejskim, bez której niemożliwe jest podejmowanie kompetentnych decyzji. Ponieważ miasta są bardzo niejednorodne przestrzennie, różnice w stukturze społeczno-ekonomicznej moga występować na niewielkich odległościach, nie tylko w skali osiedli, lecz także z ulicy na ulicę.

Obecnie wskaźniki ekonomiczne i społeczne udostępniane przez Główny Urząd Statystyczny wyliczane są do poziomu gminy (w Warszawie do poziomu dzielnic), co powoduje, że dane dla dużych miast, takich jak Poznań, Wrocław, Łódź lub Kraków, obejmują całe miasto, a stolica podzielona jest na 18 dzielnic mających nawet ponad 200 tys. mieszkańców. Wybrane dane dla największych miast prezentowane sa w podziale na 4 lub 5 delegatur urzędu miasta, jednak te jednostki przestrzenne także obejmują znaczny obszar i liczbę ludności. Sposób publikowania danych przez GUS uniemożliwia badanie procesów wewnątrz miast i prowadzi do utraty istotnych informacji na temat zmienności przestrzennej istotnych zjawisk. Ze względu na to zróżnicowanie przestrzenne zjawisk wewnątrz miast konieczne jest badanie wskaźników w bardziej szczegółowej skali przestrzennej. Z tego powodu miasta powinny prowadzić własne

${ }^{27}$ S. Lyubomirsky, L. King, E. Diener, The Benefits of Frequent Positive Affect: Does Happiness Lead to Success?, „Psychological Bulletin” 131, 2005, nr 6, s. 803-855; A. J. Oswald, E. Proto, D. Srgoi, Happiness and productivity, „Journal of Labour Economics” 33, 2015, nr 4, s. 1-41. Zob. http://www.walkscore.com/ (dostęp: 5.12.2014). 
statystyki lub postulować publikację danych statystycznych na niższych poziomach agregacji przestrzennej. Odpowiednią skalą przestrzenną prezentacji wskaźników społecznych i ekonomicznych w dużych miastach są jednostki pomocnicze samorządów, takie jak osiedla. W przypadku danych GUS-u odpowiednią jednostką przestrzenną mogą być rejony statystyczne obejmujace nie więcej niż 2700 osób. Dobrym przykładem prezentacji wskaźników społeczno-ekonomicznych w odpowiedniej agregacji przestrzennej mogą być mapy danych z amerykańskiego spisu przygotowane przez „New York Timesa”28. W Polsce można wyróżnić Atlas Miasta Łodzi opublikowany w 2002 r. i uaktualniony w $2007^{29}$.

\section{WSKAŹNIKI PRZESTRZENNE}

Wskaźniki społeczne i ekonomiczne w miastach mogą zostać uzupełnione o miary na temat warunków, jakie stwarza środowisko miejskie dla jakości życia. Zestaw takich miar można określić na podstawie opisanych wyżej czynników jakości życia i aktywności związanych z jakością życia. Dzięki możliwościom, jakie dają systemy informacji geograficznej (ang. Geographical Information Systems, GIS) ${ }^{30}$, możliwe jest ich wyliczenie w różnych skalach przestrzennych: dla całego miasta, dla jednostek administracyjnych, a nawet dla pojedynczych adresów. Można w ten sposób identyfikować miejsca o różnej dostępności do korzystnych cech i atrakcyjnych miejsc, takich jak:

- usługi użyteczności publicznej i komercyjnych,

- przystanki komunikacji miejskiej (mapa 1),

- tereny zieleni.

Miary dostępności korzystnych cech środowiska miejskiego zyskują na popularności w badaniach naukowych, zastosowaniach komercyjnych i zarządzaniu miejskim. Jednym z przykładów takich miar jest Walk Score ${ }^{31}$ wyliczany na podstawie danych Google Maps API ${ }^{32}$ wskaźnik przyjazności miast dla pieszych i rowerzystów. ParkScore ${ }^{33}$ - opracowany przez The Trust for Public Land porównuje amerykańskie miasta pod względem dostępu do parków i terenów rekreacyjnych, dostarczając takich wskaźników, jak odsetek i cechy demograficzne ludności zamieszkującej w zasięgu 10-minutowego spaceru od najbliższego terenu zieleni. Wskaźniki takie mogą być stosowane w planowaniu przestrzennym, planowaniu transportu i planowaniu wydatków budżetowych. Inwestycje i zmiany zagospodarowania powinny być wtedy kierowane w miejsca o najsłabszym dostępie do badanych usług i cech środowiska.

\footnotetext{
${ }^{28}$ Zob. projects.nytimes.com/census/2010/ (dostęp: 5.12.2014).

29 Zob. http://www.mapa.lodz.pl/atlas/temat.htm (dostęp: 5.12.2014).

${ }^{30}$ P. A. Longley et al., GIS: Teoria i praktyka, Warszawa 2006.

31 Zob. http://www.walkscore.com/ (dostęp: 5.12.2014).

32 Zob. https://developers.google.com/maps/ (dostęp: 5.12.2014).

${ }^{33}$ Zob. http://parkscore.tpl.org/ (dostęp: 5.12.2014).
} 


\section{Mapa 1}

Obszary położone w odległości 400 m lub mniejszej od przystanków komunikacji publicznej w Poznaniu

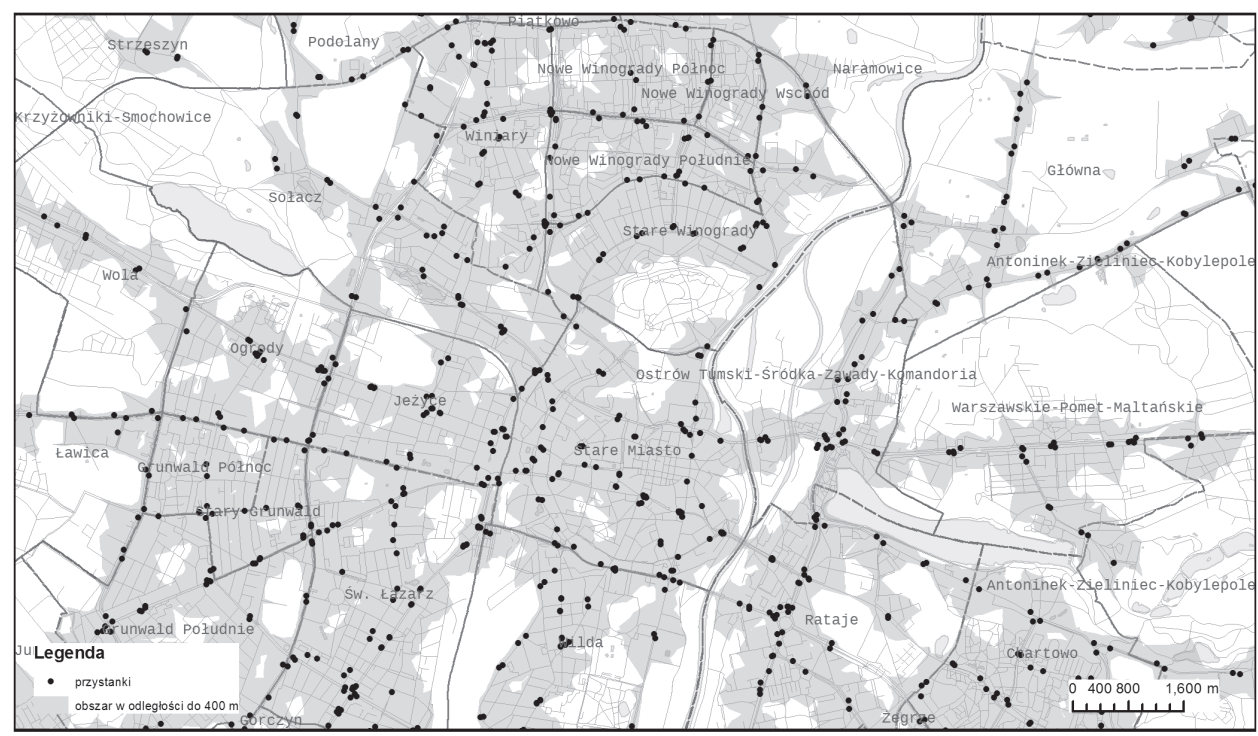

Źródło: dane o położeniu przystanków zostały pobrane z Poznań API (http://egov.psnc.pl/node/29), dane o drogach zostały pozyskane z UMP-pcPL (http://ump.waw.pl/; dostęp: 5.12.2014).

Dużą zaletą miar geograficznych opisujących środowisko miejskie jest ich porównywalność i możliwość stworzenia standardów do powielania w innych miastach. Jednocześnie jest wiele czynników psychologicznych i przestrzennych, które wpływają na postrzeganie jakości przestrzeni przez ludzi, przez co miejsca o takich samych wartościach wskaźników przestrzennych mogą w różnym stopniu spełniać potrzeby mieszkańców. W kontekście badania dostępności może być to obecność postrzeganych barier, takich jak ruchliwa ulica, niebezpieczny most, nieestetyczny i nieprzyjemny fragment trasy. Z tego względu obiektywna ocena warunków na podstawie map GIS powinna być uzupełniona o percepcję jakości przestrzeni wyrażaną przez mieszkańców.

\section{PERCEPCJA JAKOŚCI PRZESTRZENI I ZADOWOLENIE Z OTOCZENIA MIEJSCA ZAMIESZKANIA}

Badania percepcji jakości przestrzeni nie tylko dają możliwość weryfikacji wskaźników obiektywnych, lecz także umożliwiają ocenę trudno uchwytnych cech środowiska, takich jak estetyka, klimat miejsca, jakość stosunków sasiedzkich i życia społecznego, poczucie bezpieczeństwa czy przywiązanie do miejsca. Miary satysfakcji z aspektów jakości przestrzeni, powstałe na gruncie 


\section{Mapa 2}

Średnie oceny zadowolenia z otoczenia miejsca zamieszkania pod względem dostępności terenów zieleni w podziale na osiedla w Poznaniu

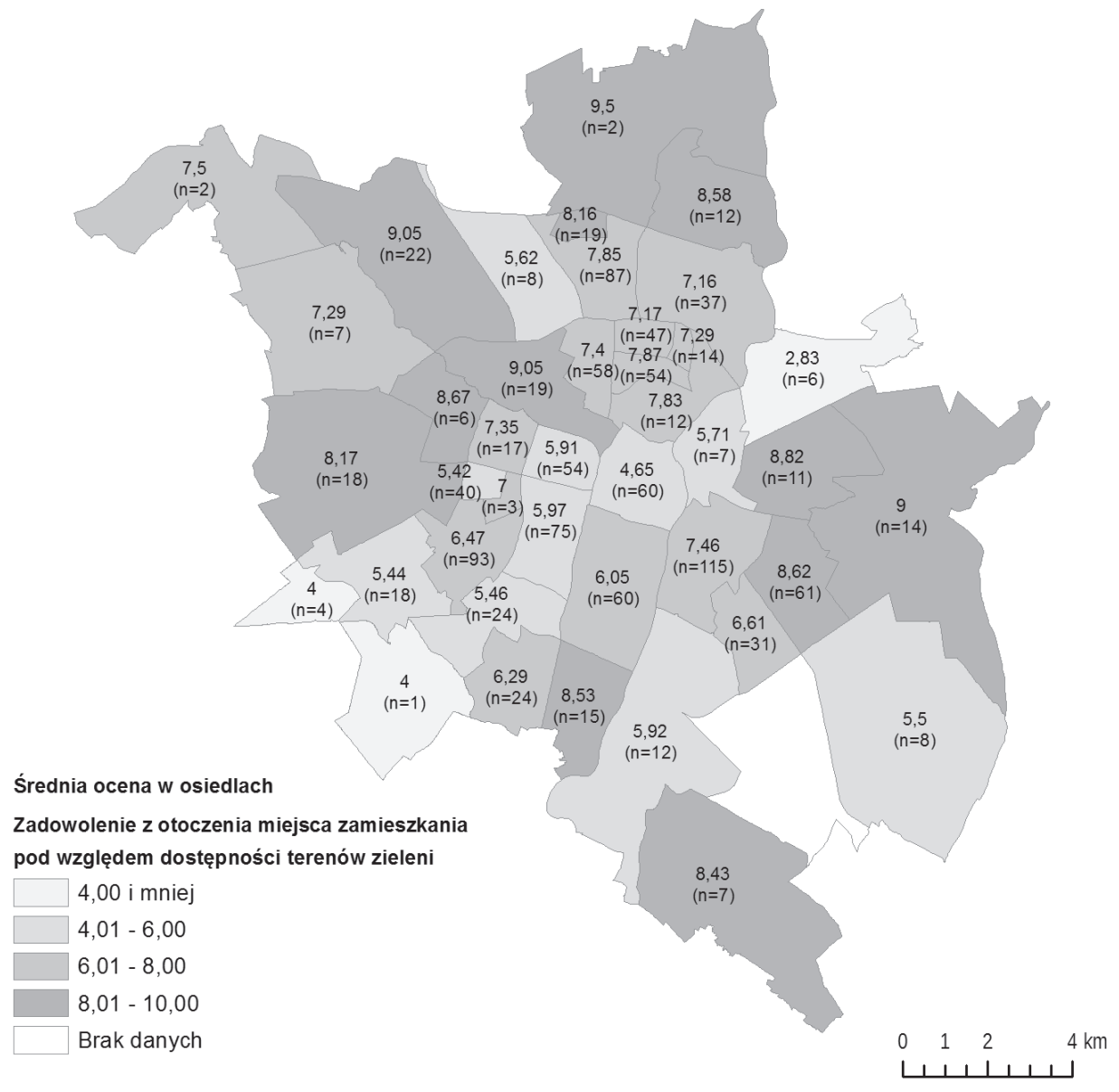

Źródło: dane pochodzą z badania w ramach projektu „Analiza przestrzenna percepcji jakości życia mieszkańców miast w kontekście rozmieszczenia zieleni miejskiej”. Satysfakcja mierzona w skali od 0 do 10. Wartość „n” oznacza liczbę pozyskanych odpowiedzi na pytanie na terenie osiedla. Wartości o niższej liczbie odpowiedzi „n” obarczone są wyższym błędem.

psychologii środowiskowej ${ }^{34}$, moga być jednym $\mathrm{z}$ elementów poznawczego aspektu dobrostanu. Mogą dotyczyć całościowej oceny jakości przestrzeni, zadowolenia z otoczenia miejsca zamieszkania lub przywiązania do miejsca. Możliwe jest także budowanie wskaźników, które agregują odpowiedzi mieszkańców na pytania o bardziej szczegółowe aspekty, takie jak infrastruktura komunikacyjna, tereny zieleni, relacje społeczne, dostępność usług publicz-

${ }^{34}$ M. Bonnes et al., Urban Environmental Quality, w: L. Steg, A. van den Berg, J. I. M. de Groot, Environmental Psychology: An Introduction, Chichester 2013. 
nych, rekreacyjnych i komercyjnych, jakość komunikacji publicznej, estetyka bądź klimat miejsca. Lista badanych aspektów może być inna, zależnie od celu badania i stosowanej metody, a także odzwierciedlać cele rozwojowe miasta. Pozyskane odpowiedzi są odnoszone do adresów lub przybliżonych miejsc zamieszkania respondentów i agregowane do dowolnych jednostek przestrzennych (mapa 2). Wyniki mogą stanowić wskazówki co do wydatkowania środków budżetu miasta, kształtowania wydatków osiedli i dzielnic oraz przygotowania projektów budżetów obywatelskich. W skali miasta wyniki mogą być wykorzystane do identyfikacji obszarów wymagających działań rewitalizacyjnych, a także jako element diagnozy miasta na potrzeby studium uwarunkowań i kierunków zagospodarowania przestrzennego.

\section{UŻYTKOWANIE I OCENA JAKOŚCI PRZESTRZENI MIEJSKIEJ}

Badanie jakości życia w mieście i jakości środowiska miejskiego może także polegać na wskazywaniu miejsc, w których realizowane sa aktywności związane z jakością życia oraz miejsc ocenianych pozytywnie lub negatywnie. Badania tego rodzaju, prowadzone na Uniwersytecie Aalto w Finlandii z wykorzystaniem metodyki softGIS ${ }^{35}$, dotyczą odwiedzanych miejsc, środków transportu oraz pozytywnych i negatywnych aspektów jakości przestrzeni i umieszczone są w kontekście dogęszczania zabudowy przy zachowaniu wysokiej jakości środowiska ${ }^{36}$.

Korzystne doświadczenia badawcze i współpraca między uczelnią a urzędem sprawiły, że kartowanie użytkowania i ocen przestrzeni publicznej przez mieszkańców jest wykorzystywane na co dzień w Urzędzie Miasta Helsinki w systemie Kerrokartalla ${ }^{37}$. Podobne badania prowadzone w Australii dotyczyły korzyści zdrowotnych i aktywnego wypoczynku w parkach miejskich ${ }^{38}$. W podobnym nurcie utrzymane sa projekty realizowane w Polsce przy udziale autorów. Projekt „Analiza przestrzenna percepcji jakości życia mieszkańców miast w kontekście rozmieszczenia zieleni miejskiej” realizowany na Uniwersytecie im. Adama Mickiewicza w Poznaniu skupia się na miarach zadowolenia z otoczenia miejsca zamieszkania (mapa 2) i rozmieszczeniu miejsc spędzania wolnego czasu (mapa 3 A i B). Projekt „Licz na zieleń” ${ }^{39}$, realizowany

${ }^{35}$ M. Kahila, M. Kyttä, SoftGIS as a Bridge-builder in Collaborative Urban Planning, Planning Support Systems Best Practice and New Methods, The GeoJournal Library, nr 95, 2009, s. $389-411$.

${ }^{36}$ M. Kyttä, Towards Contextually Sensitive Urban Densification: Location-based SoftGIS Knowledge Revealing Perceived Residential Environmental Euality, „Landscape and Urban Planning" 113, 2013, s. 30-46.

${ }^{37}$ Więcej w: M. Czepkiewicz, Systemy informacji geograficznej $w$ partycypacyjnym zarzadzaniu przyroda w mieście, „Zrównoważony Rozwój - Zastosowania” 2013, nr 4, s. 120.

${ }^{38}$ G. Brown, M. F. Schebella, D. Weber, Using Participatory GIS to Measure Physical Activity and Urban Park Benefits, „Landscape and Urban Planning”121, 2014, s. 34-44.

${ }^{39} \mathrm{Z}$ wynikami projektu i przykładową geoankietą można się zapoznać na: http://licznazielen.pl/. 
przez Fundację Sendzimira, dotyczy rozmieszczenia miejsc spędzania czasu wśród zieleni, ocen jakości zieleni miejskiej oraz identyfikacji miejsc, w których zieleni brakuje (mapa $3 \mathrm{C}$ i 4). Praktyczne wykorzystanie danych może polegać na identyfikacji miejsc szczególnie źle ocenianych przez ich użytkowników w celu kierowania tam wydatków inwestycyjnych, a także identyfikacji miejsc szczególnie popularnych i wartościowych w celu ich ochrony.

\section{Mapa 3}

Rozmieszczenie miejsc aktywności fizycznej na zewnątrz (A), spotkań ze znajomymi, przyjaciółmi i rodziną wewnątrz budynków (B) oraz miejsc, w których brakuje zieleni (C),

w Poznaniu na terenie śródmieścia i klinów zieleni
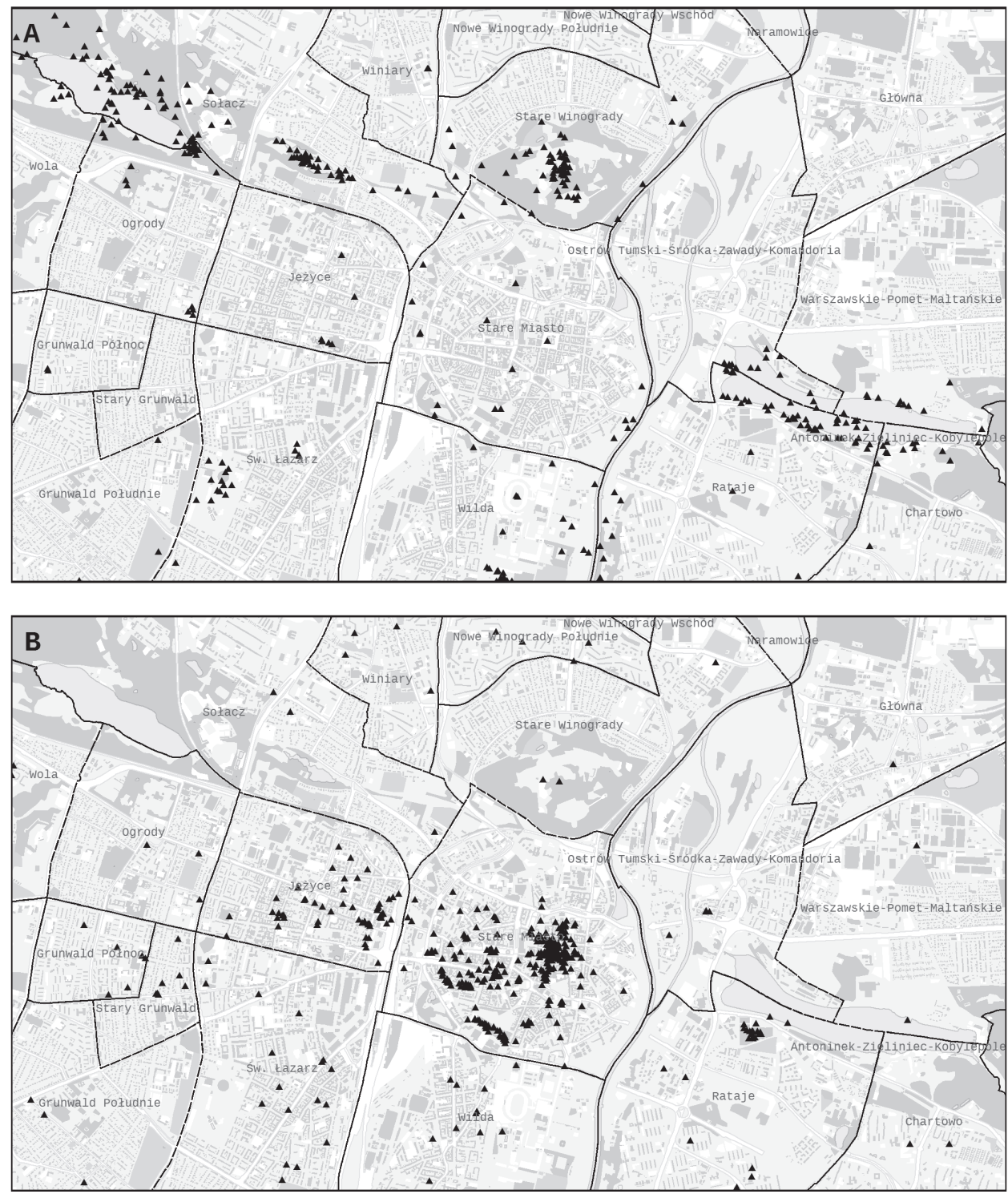


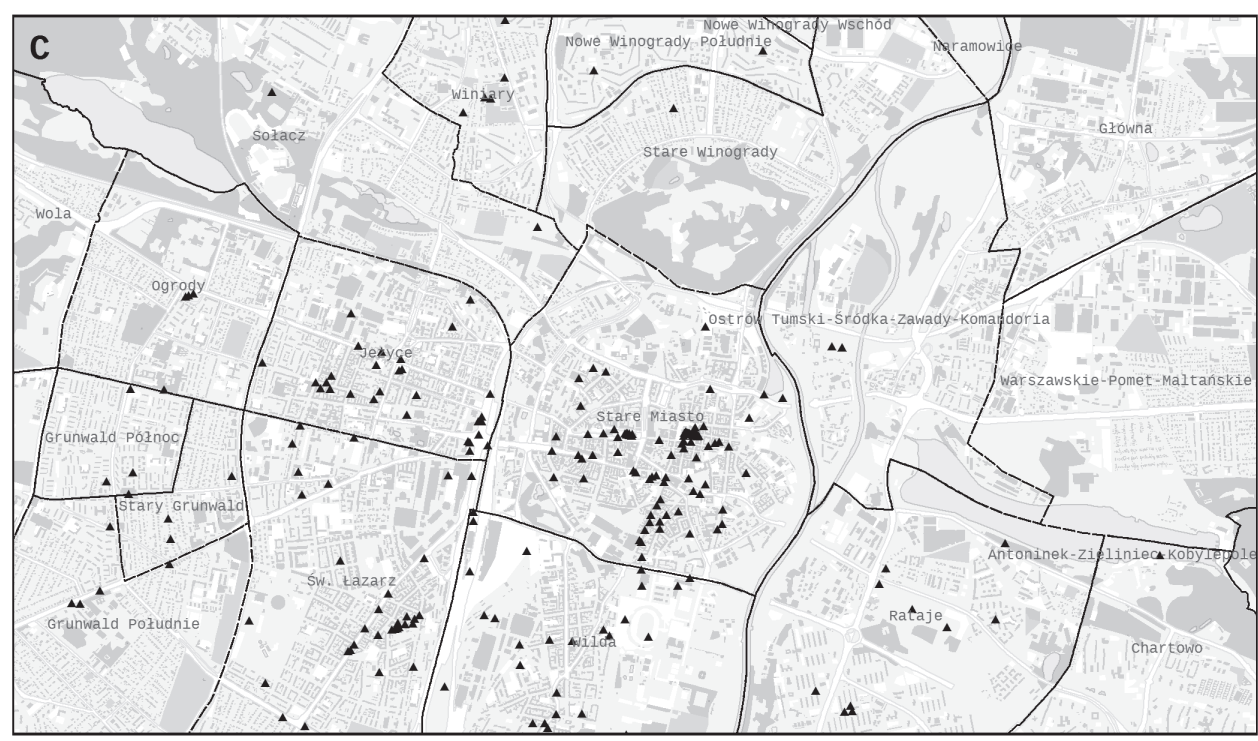

Miejsca aktywności fizycznej rozmieszczone są głównie na terenie dużych parków, lasów i innych terenów otwartych, miejsca spotkań to kawiarnie, bary i restauracje w gęsto zabudowanych dzielnicach oraz centra handlowe. Jako miejsca, w których brakuje zieleni, często wskazywane są place i ulice.

Źródło: dane pochodzą z badań z wykorzystaniem geoankiet przeprowadzonych w ramach projektów „Analiza przestrzenna percepcji jakości życia mieszkańców miast w kontekście rozmieszczenia zieleni miejskiej” (A i B) oraz „Licz na zieleń” (C).

\section{GEOANKIETY}

Dane przestrzenne dotyczące użytkowania i ocen przestrzeni moga być umieszczane na mapach papierowych lub, tak jak w wymienionych przykładach, na mapach internetowych. W tym celu wykorzystuje się geoankiety ${ }^{40}$, które pozwalaja na łączenie tradycyjnych pytań ankietowych z informacja geograficzna podawaną przez uczestników badania. Ponieważ współrzędne wprowadzanych obiektów zapisywane sa w formie cyfrowej, wiedza mieszkańców jest w łatwy sposób włączana do geograficznych baz danych. Stamtąd może być pozyskiwana razem $\mathrm{z}$ innymi danymi do wykorzystania $\mathrm{w}$ planowaniu przestrzennym, zarządzaniu zielenią lub rewitalizacji. Pytania ankietowe niepowiązane z mapami mogą dotyczyć cech demograficznych, społeczno-ekonomicznych i psychologicznych uczestników badania, a także ich preferencji wobec stylu życia, co pozwala na uwzględnienie cech indywidualnych i różnorodności potrzeb. Największą zaleta geoankiet jest pozyskiwanie cennych i niedostępnych z innych źródwł danych danych bazujących na codziennej wiedzy mieszkańców, których zebranie innymi drogami i przetworzenie jest bardzo często kosztowne i czasochłonne.

${ }^{40}$ M. Czepkiewicz, op. cit., s. 116. 
Geoankiety moga być zarówno używane w celach badawczych, jak i jako narzędzie partycypacji społecznej. Podejście badawcze wymaga zwykle zapewnienia reprezentatywnej próby losowej lub kwotowej. Oprócz spełnienia wymogów analizy statystycznej, zaleta próby losowej jest uzyskanie głosu „cichej większości”, czyli osób, które zwykle nie biorą uwagi w konsultacjach. Z drugiej strony można uznać, że każdy obywatel lub mieszkaniec powinien mieć możliwość wyrażenia swojej opinii na temat jakości przestrzeni i preferencji na temat zmian. W takim przypadku umożliwia się wypełnienie geoankiety wszystkim chętnym, pozyskując próbę otwartą. Takie podejście umieszcza geoankiety wśród metod partycypacji społecznej i partycypacyjnych systemów informacji geograficznej (ang. Participatory GIS, PPGIS) ${ }^{41}$. Przykładem partycypacyjnego wykorzystania geoankiet jest projekt „Licz na zieleń”, którego uczestnicy mogą wypowiedzieć się na temat jakości zieleni miejskiej i zaproponować zmiany (mapa 4). Wyniki projektu są prezentowane władzom samorządowym, co ma służyć wykorzystaniu ich w praktyce.

\section{Mapa 4}

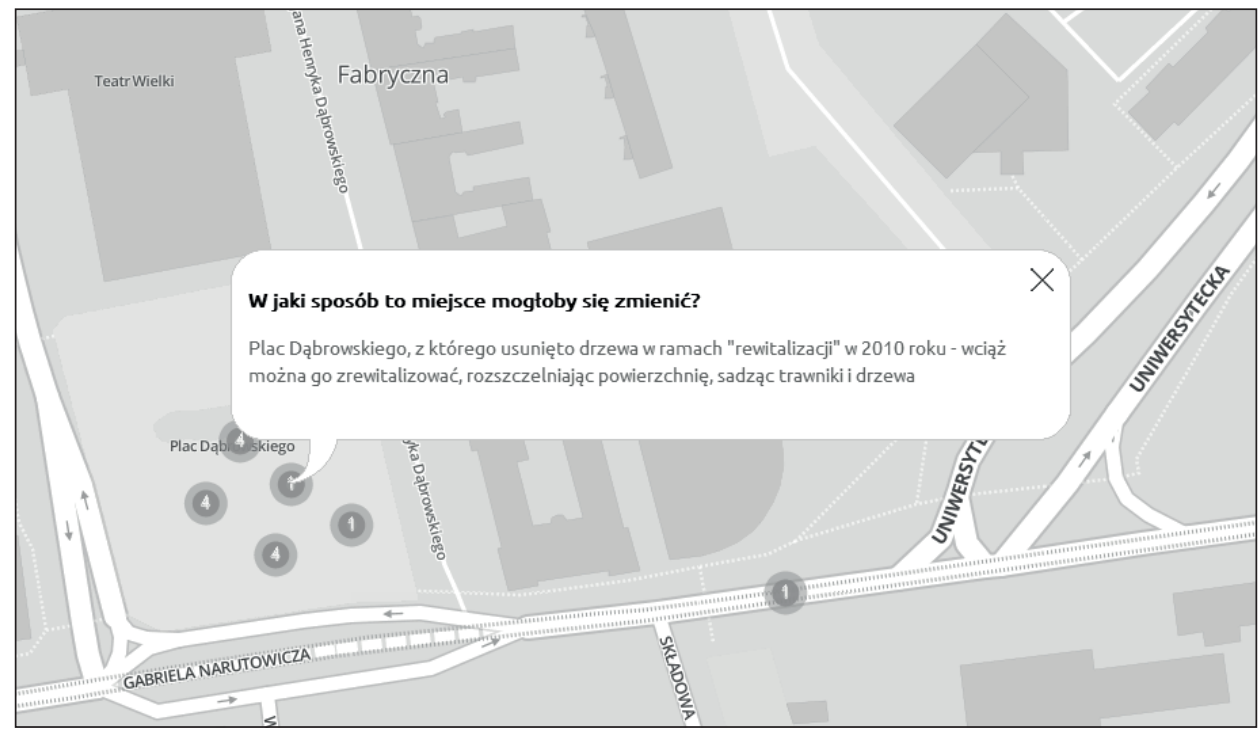

Uczestnicy badania przeprowadzonego w ramach projektu „Licz na zieleń” oznaczyli plac Dąbrowskiego w Łodzi jako jedno z miejsc, w których brakuje zieleni. Geoankieta umożliwiała dodawanie krytycznych wypowiedzi i sugestii co do przyszłych zmian na tym terenie. Z wynikami badania można się zapoznać na: http://lodz.licznazielen.pl/mapa-1/.

${ }^{41}$ P. Jankowski, Towards Participatory Geographic Information Systems for Communitybased Environmental Decision Making, „Journal of Environmental Management” 90, 2009, nr 6, s. 1966-1971; R. Sieber, Public Participation Geographic Information Systems: A Literature Review and Framework, „Annals of the Association of American Geographers” 96, 2006, nr 3, s. 491-507. 
Coraz powszechniejszy dostęp do Internetu i rosnące umiejętności korzystania z niego pozwalają juz na wykorzystanie geoankiet w praktyce przez samorządy i ich jednostki pomocnicze (np. rady osiedli), a także przez grupy mieszkańców, organizacje pozarządowe i ruchy miejskie. Wciąż jednak badania internetowe powinny być uzupełniane przez inne metody, takie jak ankiety papierowe, wywiady, warsztaty, obserwacje w terenie. Jednym z powodów są różnice w umiejętności korzystania z Internetu i preferencjach wobec korzystania z komunikacji online, prowadzące do zawyżonej reprezentacji uczestników poniżej 35 roku życia i zaniżonej reprezentacji osób powyżej 50 roku życia. Jednocześnie młodsi mieszkańcy są niedoreprezentowani podczas tradycyjnych spotkań konsultacyjnych, więc stosowanie różnorodnych metod może prowadzić do wyrównania szans uczestnictwa różnych grup i bardziej inkluzywnego procesu partycypacji. Korzystając z dotychczasowych doświadczeń, autorzy zalecają wykorzystanie geoankiet jako jednego z wielu narzędzi partycypacji oraz stosowanie różnych dróg docierania do respondentów.

\section{DYSKUSJA I REKOMENDACJE}

Zaprezentowane w artykule przykłady przestrzennego badania jakości życia dotyczyły: 1) wyliczania wskaźników społecznych i ekonomicznych w mniejszych jednostkach agregacji przestrzennej, 2) wyliczania wskaźników geograficznych opisujących fizyczne cechy środowiska miejskiego, 3) badań satysfakcji mieszkańców z różnych aspektów otoczenia miejsca zamieszkania oraz 4) badań użytkowania i ocen jakości przestrzeni miejskiej. Wśród wymienionych przykładów nie znalazły się przestrzenne badania całościowych miar subiektywnej jakości życia, takich jak miary pozytywnych i negatywnych emocji, satysfakcja z życia jako całości czy samoocena zdrowia. Choć miary te mogą być zależne od jakości środowiska miejskiego i związanych z nim możliwości i ograniczeń prowadzenia określonego stylu życia, zależności te są złożone, a ich wychwycenie wymaga uwzględnienia szeregu cech indywidualnych respondentów, badań na szeroką skalę oraz rygorystycznej metodyki. Autorzy sa zdania, że badania naukowe w tym zakresie powinny być kontynuowane i prowadzić do sformułowania wytycznych dla zastosowań praktycznych, a już teraz miasta powinny inicjować pilotażowe projekty, korzystając z wytycznych opracowanych przez takie organizacje, jak OECD i ONS. W dalszej perspektywie miary subiektywnego dobrostanu powinny zostać włączone do rutynowych badań jakości życia w polskich miastach.

Doświadczenie autorów i stan wiedzy na temat badań jakości życia pozwalają sformułować rekomendacje związane z przestrzennym badaniem jakości życia w miastach:

- Dane ze spisów ludności powinny być udostępniane na niższym poziomie agregacji przestrzennej, np. osiedli lub jednostek spisowych. Miasta powinny prowadzić własne badania wskaźników społecznych i ekonomicznych.

- Potrzebne jest utworzenie standardów, zbiorów danych i opracowań na temat korzystnych cechach środowiska miejskiego, takich jak dostępność i jakość terenów zieleni, usług komercyjnych i użyteczności publicznej, komunikacji publicznej, infrastruktury rowerowej i pieszej. 
- Miasta powinny prowadzić systematyczne, coroczne lub sezonowe, badania postrzeganej jakości przestrzeni miejskiej, zadowolenia mieszkańców $\mathrm{z}$ otoczenia miejsca zamieszkania $\mathrm{w}$ różnych aspektach oraz badania miejsc zaspokajania potrzeb mieszkańców związanych z jakością życia.

- Badania postrzeganej jakości przestrzeni miejskiej powinny być połączone $\mathrm{z}$ badaniem ich zróżnicowania względem cech indywidualnych i deklarowanych preferencji mieszkańców.

- Badania powinny być prowadzone z wykorzystaniem narzędzi internetowych i tradycyjnych oraz z wykorzystaniem warstwowanych geograficznie prób losowych oraz prób otwartych pozyskiwanych różnymi drogami.

- Powinno się kontynuować badania naukowe nad zależnościami pomiędzy miarami postrzeganej jakości życia a cechami środowiska miejskiego i formułować wytyczne do wykorzystania metodyki badań w praktyce.

Wyniki tak prowadzonych badań jakości życia powinny być dostępne dla pracowników urzędów miast, radnych miejskich i rad osiedli i stanowić punkt wyjścia do planowania przestrzennego, planowania transportu, zarządzania zielenią miejską i przestrzeniami publicznymi oraz działań rewitalizacyjnych. Diagnoza powinna być także dostępna dla organizacji pozarządowych i aktywnych społecznie mieszkańców, aby mogła się stać podstawą do dyskusji publicznej i udziału społecznego w podejmowaniu decyzji na temat wydatków budżetowych podczas konsultacji społecznych i zgłaszania projektów do budżetów obywatelskich. W ten sposób systematyczne badania jakości życia mogą stanowić ważny element opartego na wiedzy i partycypacyjnego procesu podejmowania decyzji w miastach.

W artykule zakreślono podstawy teoretyczne badań subiektywej i obiektywnej jakości życia, przedstawiono czynniki środowiska miejskiego wpływające na jakość życia mieszkańców, podano przykłady badań jakości życia w miastach z propozycjami praktycznego wykorzystania, a także nakreślono działania w kierunku uwzględnienia aspektu przestrzennego w badaniach jakości życia w miastach. By rekomendacje mogły zostać wprowadzone, potrzebne sa rozwiązania systemowe, otwartość władz samorządowych na wprowadzanie nowych metod, a także współpraca między miastami w celu wymiany doświadczeń. Potrzebne jest zainicjowanie programu systematycznego przestrzennego badania jakości życia w wielu miastach według jednolitej metodyki. Wyniki takiego programu pozwoliłyby na porównania między miastami i sformułowanie rekomendacji do dalszych badań. Autorzy artykułu wyrażaja nadzieję, że takie projekty, jak „Cities of change”, przyczynią się nie tylko do wymiany doświadczeń i wiedzy, lecz także do zmian systemowych i konkretnych działań w kierunku upowszechnienia systematycznych badań jakości życia uwględniających przestrzenne zróżnicowanie miast.

mgr Michat Czepkiewicz

Uniwersytet im. Adama Mickiewicza w Poznaniu

michal.czepkiewicz@amu.edu.pl

prof. dr Piotr Jankowski

San Diego State University

oraz Uniwersytet im. Adama Mickiewicza w Poznaniu

pjankows@mail.sdsu.edu 


\section{SPATIAL ANALYSES IN THE RESEARCH IN QUALITY OF LIFE IN CITIES}

\section{Sum mary}

Improving quality of life has always been an important goal of individuals and communities. In recent years, this objective is particularly important for cities in the context of urbanization and the migrations of urban residents to the outskirts of metropolitan areas. The authors call for the extension of the traditionally used social and economic indicators with the evaluations and perceptions of individuals, and a wider use of geographical research methods. The article presents the theoretical basis and new methods of measuring the subjective quality of life satisfaction, and quality assessment of urban space. Characteristics of the urban environment affecting activities and perceptions of the quality of life of the inhabitants are discussed. The authors propose possible areas of application of the methods presented in city management, urban planning, and regeneration, and formulate recommendations for the cities. 
